\title{
Theophoric Personal Names in Graeco-Roman Egypt. The Case of Sarapis*
}

\author{
Willy Clarysse (Leuven) and Mario C.D. Paganini (Oxford)
}

\begin{abstract}
The present study, with its concentration on the diffusion of Sarapis names, is intended to demonstrate how onomastic data, collected in computerised databases, can be useful in different ways. It took a long time before parents were prepared to give children Sarapis names, and the majority (85\%) were derivations (e.g. Sarapion, Sarapias) rather than full theophoric names (e.g Sarapadoros, Sarapammon), which occur only in Roman times. Some names like Sarapous and Sarapas are geographically limited, and a local martyr cult preseves the popularity of Sarapion and Sarapammon into the Christian period in Middle Egypt. The refinement of the statistical method may lead to wider and different questions.
\end{abstract}

Keywords: Egyptian religion, Sarapis cult, Greek onomastics, martyrs cults, theophoric names

Personal names are an ubiquitous feature of both papyrological and epigraphical sources. In fact papyri or inscriptions not mentioning any personal name are rather exceptional. As the names change with time, place and social class, they form an excellent source for quantitative studies. Thanks to the Duke Databank of Documentary Papyri, it is now possible to list every single instance of a personal name in the papyrus documentation (epigraphy lags behind here) and to map in detail the spread of names. Thus onomastic studies can for the first time make use of statistical data to see and present the rise and decline of personal names through the millennium between Alexander and Mohammed.

As many ancient personal names refer to gods, they contain indirect information about the spread and the popularity of ancient cults. This has been shown by scholars such as E. Sittig ${ }^{1}$ and time and again by L. Robert. ${ }^{2}$ For Egyptian gods there is a useful survey by Th. Hopfner, ${ }^{3}$ and some excellent articles by $\mathrm{H}$. De Meulenaere and M. Thirion. ${ }^{4}$

\footnotetext{
* We thank E. Aerts for commenting upon an earlier version of this article.

${ }^{1}$ E. Sittig, De Graecorum nominibus theophoris (Halis Saxonum 1911).

${ }^{2}$ See for instance L. Robert, Noms indigènes dans l'Asie Mineure méridionale (Paris 1963) and his numerous contributions in the Bulletin épigraphique, REG 51-97 (1938-1984); see also O. Masson, Onomastica Graeca Selecta 1-3 (Paris 1990-2000).

3 Th. Hopfner, ,Graezisierte, griechisch-ägyptische, bzw. ägyptisch-griechische und hybride theophore Personennamen aus griechischen Texten, Inschriften, Papyri und Ostraka, Mumientäfelchen und dgl. und ihre religionsgeschichtliche Bedeutung', Archiwum Orientale Pragense 15
} 
In a pioneering study on the cult of Sarapis in 1960 P.M. Fraser used onomastic data to illustrate the spread of a new cult. ${ }^{5}$ From the dedicatory inscriptions and the names Fraser concluded that the cult was propagated by the first Ptolemies in the third century BC, he argued that ,the appeal of Sarapis in Ptolemaic Egypt and in Alexandria was very restricted' (p. 9) and that ,Sarapis-names barely occur in Alexandria before the Roman period' (p. 19). The diffusion of the cult outside Egypt was considered due to private initiative, not to Ptolemaic state intervention. Though he briefly touched upon the spread of the Sarapis cult in Roman Egypt (p. 19), this problem fell outside the scope of his subject.

Fraser's approach was of necessity impressionistic. Now, half a century later, we revisit the subject, basing ourselves upon hundreds of new texts, and expanding Fraser's study into the Roman and Byzantine periods. Perhaps even more important, computer technology allows us to quantify the data far more precisely, though not yet as precisely as we would wish.

Sarapis offers an interesting case study precisely because he is a new god, developed or created from the Egyptian Osiris-Apis, whose cult spread from Memphis to Alexandria and from Egypt through the Mediterranean and even beyond. ${ }^{6}$ In contrast to names which refer to the gods of old, such as Zeus or Apollo, most Sarapis-names 7 are not compounds of the type Diodoros or Apollodotos, but rather derivations. ${ }^{8}$ The two main names are Sarapion for men and

(1946) 1-64. See now also W. Clarysse and D.J. Thompson, Counting the People in Hellenistic Egypt 2 (Cambridge 2006) 332-341.

4 H. De Meulenaere, ,Notes d'onomastique tardive‘, R.Egypt. 11-14 (1957-1960) and M. Thirion, ,Notes d'onomastique. Contribution à une révision de Ranke, PN`, R.Egypt. 31-56 (1979-2005), passim.

5 P.M. Fraser, ,Two studies on the cult of Sarapis in the hellenistic world', Opuscula Atheniensia III, Skrifter utgivna av Svenska Institutet $i$ Athen (Acta Instituti Atheniensis Regni Sueciae) 7 (1960) 1-54 (onomastics in Egypt: 14-16).

${ }^{6}$ One of the earliest examples of the cult is found in Hyrcania, near the Caspian Sea, where a slave is manumitted in the local temple of Sarapis in the time of Antiochus I (281-261 BC). The text was published by L. Robert, Hellenica 11-12 (Limoges 1960) 85-91 (= SEG 20.325) in the same year as Fraser's article. Recent re-editions can be found in F. Canali De Rossi, Inschriften griechischer Städte aus Kleinasien 45 nr. 280 and in L. Bricault, Recueil des inscriptions concernant les cultes isiaques 2 (Paris 2005) 515.405/0101. A remarkable example of the late Roman period is found in Amm. Marc. 16.12.25, where Mederichus, king of the Alamanni, changes the name of his young son from Agenarichus to Serapio shortly before AD 357.

${ }^{7}$ Sarapis-names include 18 variants - in brackets the number of attestations in Egypt (Eg.) and outside Egypt (o.Eg.), if any: Diosarapis (Eg. 1), Philosarapis (Eg. 41; o.Eg. 1), Sarammon (Eg. 13), Saranoupis (Eg. 1), Sarapammon (Eg. 525; o.Eg. 2), Sarapaphrodisios (Eg. 1), Sarapas (Eg. 190; o.Eg. 12), Sarapiades (Eg. 15; o.Eg. 1), Sarapiaina (Eg. 1), Sarapiakos (Eg. 17; o.Eg. 3), Sarapias (Eg. 345; o.Eg. 42), Sarapion (Eg. 3319; o.Eg. 330), Sarapodidymos (Eg. 1), Sarapodioskoros (Eg. 2), Sarapodora (Eg. 9; o.Eg. 1), Sarap(i)odoros (Eg. 81; o.Eg. 9), Sarapollon (Eg. 3; o.Eg. 1), Sarapous (Eg. 80; o.Eg. 5), Tasarapion (Eg. 4), Tasarapis (Eg. 1).

${ }^{8}$ For the difference between compound and suffixed names, see for instance R. Parker, ,Theophoric names and Greek religion', in S. Hornblower and E. Matthews (eds.), Greek personal names. Their value as evidence (Proceedings of the British Academy 104, Oxford 2000) 59-62. 
Sarapias for women. ${ }^{9}$ Personal names based upon the name of the god illustrate the spread of his cult, with a certain delay (as new name bearers become visible only when they act as adults), but once names have gained popularity they can also continue through family traditions. New variants can develop, such as Sarapas (masculine) and Sarapous (feminine) in the Roman period.

\section{The Database}

Our database includes all Sarapis-names in the sources from Egypt or mentioning Egyptians, both papyri and inscriptions. ${ }^{10}$ Names abbreviated in Sarap( ) have been included, names abbreviated in Sara( ) have been omitted, unless the person could be identified with a known bearer of a Sarapis-name. The following information is provided:

- Names and prosopography

To the material from the Duke Data Bank of Documentary Papyri we have added numerous inscriptions and a few persons attested in ancient authors and in demotic texts. When one person appears several times in different sources, e.g. the owner of the Sarapion archive, the strategoi called Sarapion who functioned in the second century Arsinoites or some taxpayers in Karanis or Theadelpheia, we have grouped these references whenever possible. ${ }^{11}$ Thus the statement ,90 Sarapis names' means ,90 different persons bearing a name based on Sarapis'. In order to make possible an identification, however, some extra information is necessary: if a Sarapion occurs in a fragmentary list, without exact provenance and without exact date, he will necessarily remain unidentified and therefore be listed as a separate person in our database. It can therefore not be avoided that instances in which information is minimal, may refer to the same person in other texts. We hope that on average the number of overlaps will be the same over different periods and different groupings of documents, though clearly the danger is greater with individual ostraca than in long tax lists where individual persons can be identified far more easily (e.g. at Karanis).

\footnotetext{
${ }^{9}$ Sarapia is not found in Greek, though it sometimes renders Sarapias in Latin; see M.C.D

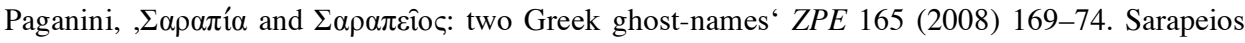
and Seraponymos have been identified as ghost-names by Paganini and Masson respectively (see O. Masson, in Bulletin épigraphique, REG 103 (1990) nr. 808).

${ }^{10}$ Names outside Egypt have been collected in a separate database, which is not taken into account for statistical purposes because it is still incomplete.

${ }^{11}$ We have, for instance, supplemented the patronymic of Sarapion in P.Schoyen inv. 180 col.

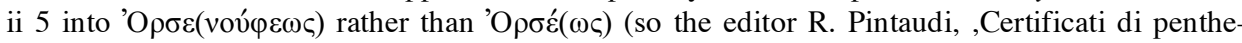
meros da Tebtynis nella collezione Martin Schøyen (MS 180)', CE 80 (2005) 217), identifying Sarapion son of Orsenouphis with the person of the same name in $S B$ I 5124.159.
} 
- Date

Though the database lists individual dates, in our study we have mainly worked by century only. Sources dated ,first or second century ' have received a half reference for each century. Ideally one should work with generations of 30 or 20 years (the average generation span). This may become possible in the future thanks to the dating system of the Heidelberger Gesamtverzeichnis. Ideally one should also start from the date of birth of each person and therefore deduct at least 20 years from his first appearance (in cases where an exact age is given, this should of course be taken into account), 50 years for fathers/mothers and 80 years for grandparents. ${ }^{12}$ This desideratum may be realised in a not so distant future by means of a tagging system based on the Duke Databank which is being elaborated in a Leuven project, started by Mark Depauw.

\section{- Provenance}

Here we have indicated the nome in which the text is written, accepting that persons mentioned in a text from the Oxyrhynchite nome were as a rule born and bred in that nome. Sometimes a person came from elsewhere (e.g. in the Roman period strategi functioned outside their own nome) or was active outside the place where a text was written (e.g. a person writing a letter from Alexandria to his family in Oxyrhynchus). These individuals are registered according to their actual provenance. Alexandrian or Antinoite landlords in the Oxyrhynchite or Hermopolite nome, for instance, have been counted as Alexandrians and Antinoites.

We have also included information on the social class of the bearers of Sarapis names and on the linguistic affiliation (Greek or Egyptian) of their families (patronymics, metronymics, children).

We are well aware that the distribution of our documentation is based in several aspects: men are far better represented than women (92 vs. $8 \%$ ), the Fayum and the Oxyrhynchites make up $62 \%$ of our persons, the higher social classes and especially those working in army and administration are clearly over-represented. We are best informed about upper class males in Middle Egypt.

\section{Using the Database for Quantification}

In order to establish the popularity of a name it does not suffice to count the number of persons carrying that name in a certain place or a certain period. The number of Sarapis-names in Egypt, 4857 in all, goes down from 485 in the fourth century AD to 91 in the fifth century and up again to 102 in the sixth century. ${ }^{13}$ But this does not point to a revival of these names in the sixth century, because from

\footnotetext{
${ }^{12}$ For the average age of the parents at the birth of their children, see R.S. Bagnall and B.W. Frier, The demography of Roman Egypt (Cambridge 1994) 135-46 (average age of maternity is 27 years, of paternity 35 years).

${ }^{13}$ Counting happened in June 2009. Texts dated in the third-second century have been counted as belonging half to each of the two centuries.
} 
that century many more persons are known than from the fifth. What we need to establish is the percentage of individuals with Sarapis-names in each period (or place): what matters is relative frequency, not absolute numbers. In the foreseeable future it might become possible to list all known individuals by generation and to match for each generation the percentage of bearers of a certain name or of a certain type of name (e.g. monotheistic names or Egyptian names beginning with Pete-/Tete-). At this moment we are still far from such an ideal situation. We have therefore counted the number of texts by century on the basis of the Heidelberger Gesamtverzeichnis ${ }^{14}$ and Trismegistos online, counting only papyri and only those that can be attributed with certainty to one century or the overlap of two centuries. As a working hypothesis we have accepted that the number of persons is to a certain extent related to the number of texts in each century, i.e. that texts from different periods contain more or less the same number of persons by text. In col. 4 of the table below we have compared the number of Sarapisnames with the number of texts by century to map the popularity of our names over time.

\begin{tabular}{|l|c|c|c|}
\hline Century & $\begin{array}{l}\text { number of } \\
\text { persons with a } \\
\text { Sarapis-name }\end{array}$ & $\begin{array}{l}\text { number of texts } \\
\text { (HGV via } \\
\text { Trismegistos) }\end{array}$ & $\begin{array}{l}\text { number of Sarapis- } \\
\text { names for 1000 } \\
\text { texts }\end{array}$ \\
\hline III BC & 33 & 4238 & 8 \\
\hline II BC & 123 & 3487 & 35 \\
\hline I BC & 99 & 1755 & 56 \\
\hline AD I & 423 & 4841 & 87 \\
\hline AD II & 1297 & 14850 & 143 \\
\hline AD III & 485 & 9309 & 139 \\
\hline AD IV & 91 & 5060 & 95 \\
\hline AD V & 102 & 3778 & 47 \\
\hline AD VI & 61 & 4021 & 26 \\
\hline AD VII & & &
\end{tabular}

The picture is visualised in the following graphs:

14 These figures contain all texts certainly dated to a century and (half of) those which are spread over two centuries. They are in fact an update of those in W. Habermann, ,Zur chronologischen Verteilung der papyrologischen Zeugnisse', ZPE 122 (1998) 144-160, with the help of D. Hagedorn. 
Graph 1: Sarapis-names, absolute figures (number of persons by century)

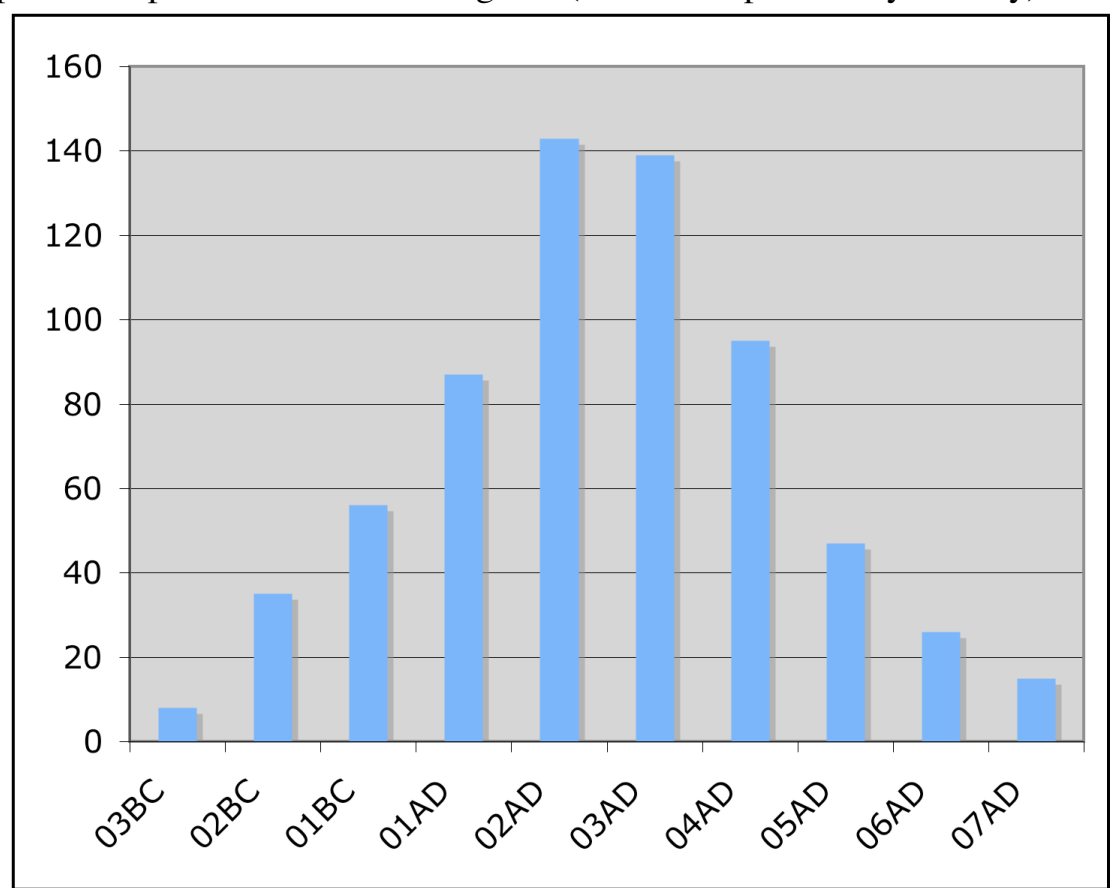

Graph 2: Sarapis names, relative figures (number of persons called Sarapion 1000 texts)

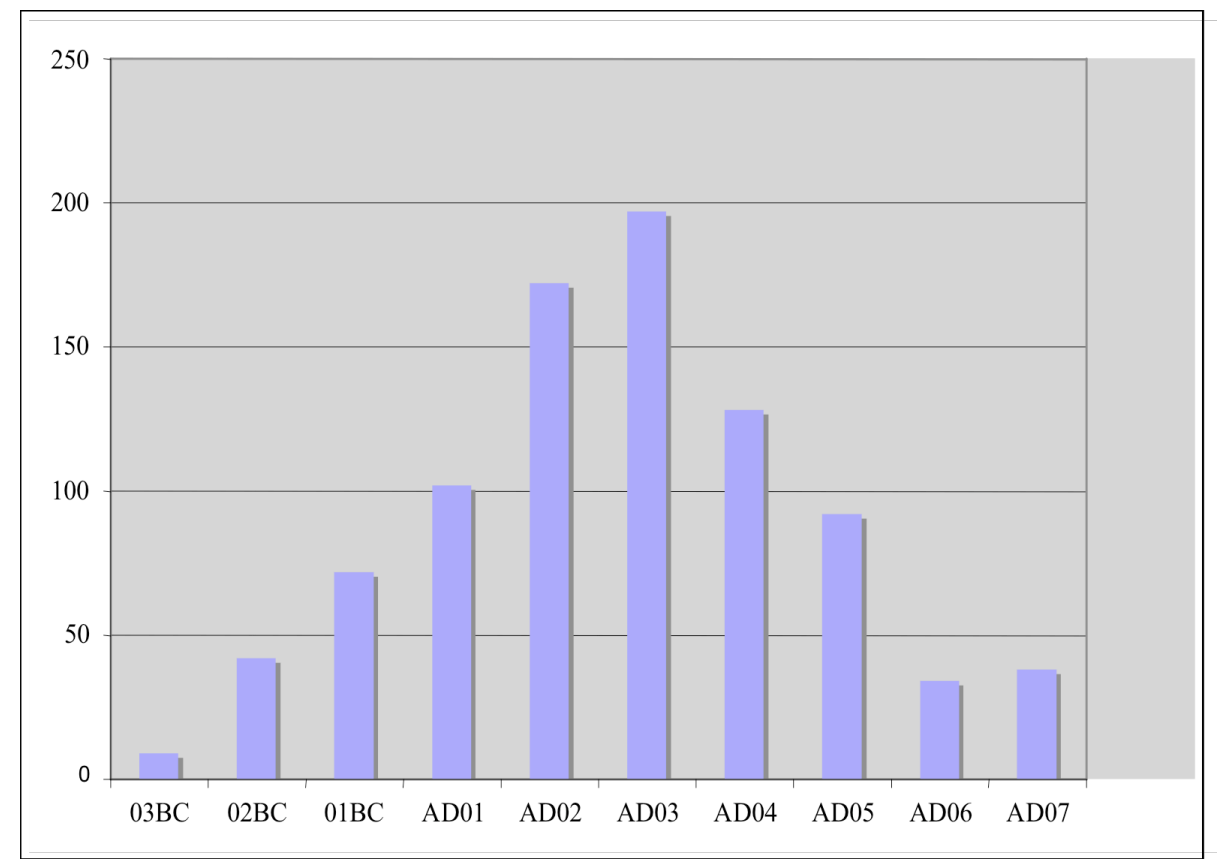


Sarapis-names are largely absent before 220 BC (see below sub 3) and gradually gain in popularity during the later Ptolemaic period, as Fraser rightly saw. They reach their greatest popularity in the second and third centuries and appear nearly three times as often around AD 200 than at the beginning of the Roman period. Since within the fourth century only 41 texts on a total of $485(18 \%)$ date from 360 or later, the decline was most rapid in the second half of the century (when adults who received their names in the pagan empire were dying out).

\section{The Earliest Examples}

Since Sarapis-names are rare before the late third century BC, we here offer a survey of the earliest examples, supplementing and correcting Fraser's listing. ${ }^{15}$ References in Fraser which we consider spurious have been put in square brackets.

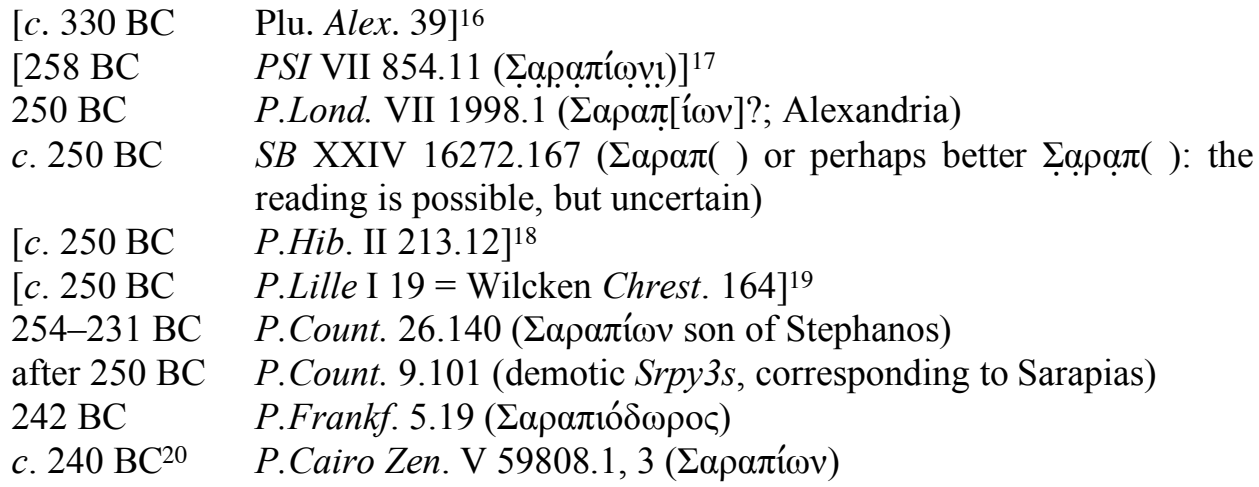

15 Fraser (n. 5) 14-6 with footnotes. SEG 2.866 (Thmouis) and $C I G 4682$, mentioned by Fraser $16 \mathrm{n}$. 1, have not been included in our list. The former is dated generally to the Ptolemaic period by the editor, the latter is dated to $134 \mathrm{BC}$ in the re-edition I.Louvre I 17.

16 This example is considered anachronistic by H. Berve, Das Alexanderreich auf prosopographischer Grundlage 2 (München 1926) 352-3 and Fraser (n. 5) 14 n. 3. It was defended by C.B. Welles, ,The discovery of Sarapis and the foundation of Alexandria', Historia 11 (1962) 288 and by J.R. Hamilton, Plutarch Alexander. A commentary (Oxford 1969) 103. In our opinion, even if Sarapis was already known in some form in the last years of Alexander, a personal name derived from that god, nearly three generations before the first documentary example, is unlikely.

17 The reading is highly doubtful, as can be seen on the plate given by G. Messeri Savorelli and R. Pintaudi, I papiri dell'archivio di Zenon a Firenze (Pap. Flor. XXIV, Firenze 1993) pl. 26.

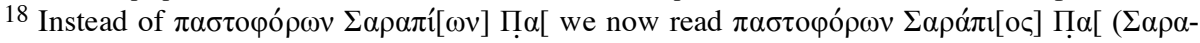
$\pi \mathrm{r}$ [ is the name of the god, not that of the first priest in the list): $c f$. W. Clarysse, ,Notes on papyri', ZPE 168 (2009), p. 243.

${ }^{19}$ Dated mid third century by the editor and to $232 / 31$ by M.I. Rostovtzeff, A large Estate in Egypt in the Third Century BC: a Study in Economic History (Madison 1922) 171. Fraser (n. 5) 16 n. 1 considers this as ,probably the earliest known bearer of a Sarapis name'. For its new date (145 $\mathrm{BC})$, see the re-edition in $S B \mathrm{XX} 15150$. 
238-224 BC P.Petrie ${ }^{2}$ I 30.10 (the son of the testator is called $\Sigma \alpha \rho \alpha \pi i \omega v$ )

233-225 BC $\quad P P$ VI $14690(\Sigma \alpha \rho \alpha \pi i ́ \omega v)$ (Hadra vase from Alexandria) ${ }^{21}$

before 232 BC P.Count. $6.266(\Sigma \alpha \rho \alpha \pi[i ́ \omega v])$

$[231 \mathrm{BC} \quad S B \text { VI } 9258=\text { P.Yale I } 37]^{22}$

$230 \mathrm{BC}^{23} \quad P . R y l$. IV $573\left(\Sigma \alpha \rho \alpha \pi^{\prime} \omega v\right)$

224 BC P.dem. BM Andrews 35 verso (demotic Srpyn, i.e. $\Sigma \alpha \rho \alpha \pi i ́ \omega v$, son of Harmiysis, witness in a demotic document)

c. 220 BC P.Petrie II 43.53 (Sarapion son of Nikias) ${ }^{24}$

Sarapis-names are not attested before $250 \mathrm{BC}$ and rare before the last quarter of the third century. The rich prosopography of the Zenon archive offers one certain example of 240 BC (P.Cairo Zen. V 59808) and one nearly certain of 250 BC (P.Lond. VII 1998); we have no reason to identify the two homonyms. All other certain instances may in fact belong to the 230's. Most surprising is Sarapiodoros in P.Frankf. 5: where the editor read $\Sigma \alpha \rho \alpha \pi i \omega v$ the papyrus clearly has $\Sigma \alpha \rho \alpha \pi t o ́-$ $\delta \omega \rho \circ \varphi^{25}$

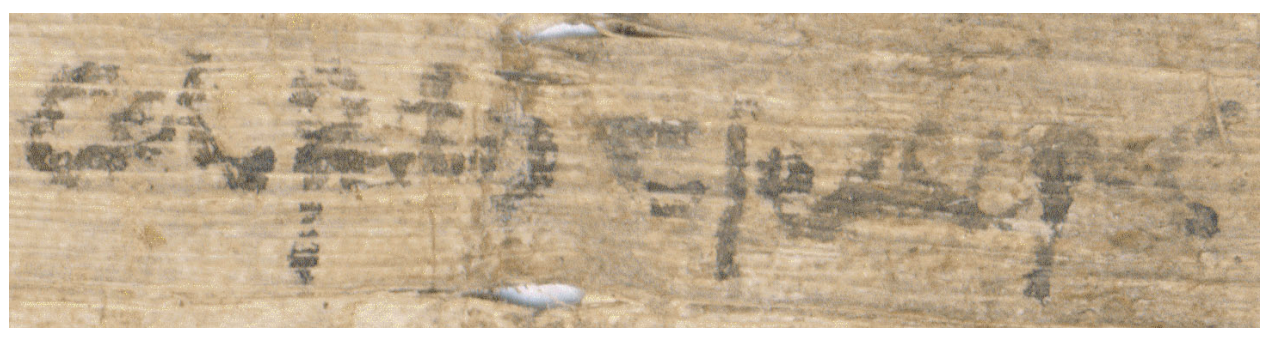

This name is otherwise not attested before the imperial period (see below). The person in question is an uncle of the declarant and may therefore have been born about $280 \mathrm{BC}$ or even earlier.

Similarly, Sarapis names outside Egypt are not attested before the late third or early second century BC: Sarapion son of Sarapion in $\operatorname{MDAI}(A) 28$ (1903) $353 \mathrm{nr}$.

\footnotetext{
${ }^{20}$ For the date, see H. Hauben, ,Kriton, stolarque au service d'Apollonios le diøcète', Anc.Soc. 36 (2006) 196 nr. 17; the editor C.C. Edgar had dated the letter in 257 BC.

${ }^{21}$ In OGIS I 37 and $S B$ V 8767 the funerary urn is dated in the reign of Ptolemy II; it was placed under Ptolemy III by $\mathrm{H}$. Braunert, see $B L 4.84$.

22 The exact date is $190 \mathrm{BC}$, not $231 \mathrm{BC}(c f . B L 8.513)$. This text is therefore wrongly adduced as an early Sarapion by Parker (n. 7) 75 n. 82.

23 The text is dated in a seventeenth year attributed to Euergetes by the editors; the sums mentioned go down to obols, which suggests a date before 211 BC. Though the title archisômatophulax (1. 6), is unexpected before the reign of Epiphanes, the third century date is accepted by L. Mooren, The Aulic Titulature in Ptolemaic Egypt. Introduction and Prosopography (Brussels 1975) 79 nr. 039.

${ }^{24}$ Dated generally ,third century ' by the editor and by Fraser (n. 5) 16 n. 1, this text is contemporary with P.Lille dem. II 50-51 (223 BC); see P.Horak., 280.

${ }^{25}$ We thank B. Sirks for providing us with the image.
} 
1.8 (from Samos) is the only, third century BC' example in LGPN I 401. However, the recent re-edition in $I G$ XII $6.1 \mathrm{n} .180$ has brought it down to $c .200 \mathrm{BC}$.

It is unclear whether the slow spread of Sarapis-names results from a lack of popular interest. Family naming traditions are not easily broken up. Whereas dynastic names, such as Ptolemaios, Arsinoe or Philotera, are popular in court circles from the mid third century onwards (see the lists of eponymous priests in Pap. Lugd. Bat. XXIV), Sarapis names are conspicuously absent and were clearly not felt as a way to express loyalty to the Ptolemies.

\section{Sarapis and Serapis}

There is no doubt that Sarapis and Serapis refer to the same god: the two forms are often used for the same person, sometimes even within the same text. ${ }^{26}$ For Egypt, the often repeated statement that Ptolemaic Sarapis was replaced in the Roman period by Serapis ${ }^{27}$ is not confirmed by our data. In fact the forms with Ser- are a small minority throughout (less than 10\%) and the percentage even slightly decreases in the Roman and Byzantine periods.

\begin{tabular}{|l|c|c|r|}
\hline & Total Sarapis-names & Serapis variants & $\%$ \\
\hline BC & 255 & 20 & 7.8 \\
\hline AD I-IV & 4321 & 263 & 6.1 \\
\hline AD V-VII & 251 & 10 & 4 \\
\hline
\end{tabular}

Some of the oldest Greek transcriptions faithfully render the name of OsirisApis as Osor-apis, e.g. the name of the deified sacred bull in the katochoi archive (UPZ I 19; 54; 106-109). In the well-known petition of Artemisia (UPZ I 1), written in Memphis before Ptolemy I established the Greek cult, the god is called

${ }^{26}$ E.g. Serapas/Sarapas in P.Oxy. IV 722.21 and 37; Serapous/Sarapous in P.Mich. V 326.9 and 17; Serapion/Sarapion father of Aion(is) in P.New York I 11 and P.Col. VII 152; idem in P.Hamb. IV 274.8 and 275.8; P.Fouad 28.8 and 18-19; P.Mich. VIII 513.1 and 13; Serapias/Sarapias in P.Mich. IV.4165 and 4286; the praktôr Serapammon/Sarapammon in Elephantine (O.Bodl. II 806; 817; O.Wilcken 173-86 passim; P.Bingen 89), etc. The Oxyrhynchite village Sarapion Chairemon is written as Serapion Chairemon in P.Wash. 81.12.

27 P.M. Fraser, Ptolemaic Alexandria 1 (Oxford 1972) 246: ,Sarapis, or as he was later called Serapis'; U. Wilcken, $U P Z$ 1, 86: ,Erst in der Kaiserzeit ist die Form $\Sigma \dot{\varepsilon} \rho \alpha \pi \iota \varsigma$ die übliche geworden“; E. Bernand, I. Philae 2, 206: ,Serapion est la forme usuelle à l'époque impériale‘; L. Vidman, Isis und Sarapis bei den Griechen und Römern. Epigraphische Studien zur Verbreitung und zu den Trägern des ägyptischen Kultes (Berlin 1970) 24: ,Nur nebenbei sei bemerkt, dass die Form

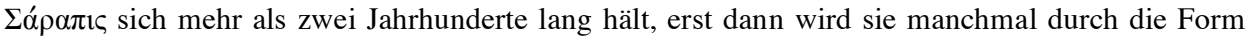

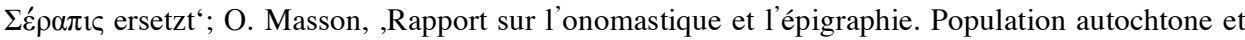
population étrangère (dans le monde hellénistique)', in A. Fol, V. Zhivkov and N. Nedjalkov (eds.), Acta Centri historiae Terra Antiqua Balcanica 2 (Trinovi 1987) 303: ,Sarapis, plus tard Sérapis‘; J. Quack, Der Neue Pauly (2001) 445, s.v. Serapion: ,in späteren Quellen Serapis‘. 
Oserapis and his temple Poserapi. Osor-apis is also found in Egyptian personal names such as Petosorapis and Peteusorapis (where $\varepsilon v$ corresponds to $\varepsilon 0$ ).

No third century BC example of Serap- has turned up to date. The earliest dated example of a Serapis-name in Egypt is from 138 BC (SB I 6184), though the form with epsilon is already attested for the temple Serapieion in $187 \mathrm{BC}$ (P.Tebt. III 774.27). ${ }^{28}$ In the katochoi archive (about $160 \mathrm{BC}$ ) the usual form is Sarapis and Sarapieion, only twice is the temple called Serapieion (UPZ I 3.2; 120.9). The god is regularly called Serapis in the mid second-century BC manumission inscriptions from Chaironeia (IG VII 3322-3406 passim).

The only significant grouping of Serap-names is found in the ostraca of the eastern desert. Here Serap-names are as common as Sarap-names (32 instances out of 65 names). In Elephantine the percentage of Serapis-names is also above average (14 out of 43, or 32,5\%). Serapis, not Sarapis, is the usual form in Latin, ${ }^{29}$ both in the authors ${ }^{30}$ and in the inscriptions. ${ }^{31}$ Perhaps in the Roman army context the form Serapis was due to Latin influence. Interchange of a and e is found also in other Latin loanwords. ${ }^{32}$ But Latin does not explain the instances of the earlier period and cannot, therefore, be the sole explanation. Among Sarapis names in the Hellenistic Greek speaking world Serapis forms also make up one third of the preserved examples (43 on 181). Apparently the form Serap- was more popular abroad than in Egypt. ${ }^{33}$

\footnotetext{
28 Outside Egypt an early Serapion is attested as a patronymic shortly after 190 BC in Miletus (SEG 45.1606.7). On 1. 15 of the same text the same (?) father is called Sarapion. In Attica Sarapis forms predominate in the Hellenistic and early Roman period, Serapis forms take over after AD 100, cf. L. Threatte, The grammar of Attic inscriptions 1 (Berlin, New York 1980) 122-5 with a full list of examples.

${ }^{29}$ See, for instance, H. Solin, Die griechischen Personennamen in Rom 1 (Berlin, New York 1982) 408.

30 A. Forcellini, Lexicon totius latinitatis 6 (second reprint of 4th edn., 1965) 615-6 s.v. Serapis.

${ }^{31}$ See, for instance, Solin (n. 27) 408. A quick count based on M. Malaise, ,Inventaire préliminaire des documents égyptiens découverts en Italie', EPRO 21 (1972) 368-369, shows that out of 88 instances for the god Sarapis for the whole of Italy 57 are vocalised Serapis and 31 Sarapis. Among the Serapis-names 47 out of 57 (82\%) are found in Latin inscriptions, whereas 22 out of the 31 Sarapis-names occur in Greek inscriptions $(70 \%)$.

32 F.T. Gignac, A grammar of the Greek papyri of the Roman and Byzantine periods 1 (Milano 1976) 279 .

33 Of the 20 Serap-names for Ptolemaic subjects, two are found on inscriptions in Greece (I.Cret. IV 215; A. Maiuri, Nuova silloge epigrafica di Rodi e Cos (Firenze 1925) nr. 503) and two in literary texts from the Roman period (PP VI 16552; 17115). No less than nine are found on the inscriptions I.Herm. 5 and 6. If these are not taken into account, Serap-forms are as rare in Ptolemaic times as later.
} 


\section{The Greekness of the Names}

Sarapis was a Greek god ${ }^{34}$ and personal names containing his name are also Greek. The Egyptian equivalent Osorapis is found in Egyptian proper names such as Petosorapis (never Pete-sarapis or Peto-sarapis). ${ }^{35}$ The Greek character of the name is confirmed by the other names used in the same families. We have limited ourselves here to parents-children combinations, where one of the two has a name with Sarap-. These yield the following figures:

\begin{tabular}{|l|c|c|c|}
\hline & Greek-Greek & Greek-Egyptian & Egyptian-Greek \\
\hline father - son & 1765 & 162 & 229 \\
\hline father - daughter & 176 & 38 & 8 \\
\hline mother - son & 186 & 10 & 108 \\
\hline mother - daughter & 22 & 7 & 9 \\
\hline
\end{tabular}

Graph 3 : Greek and Egyptian names over two generations

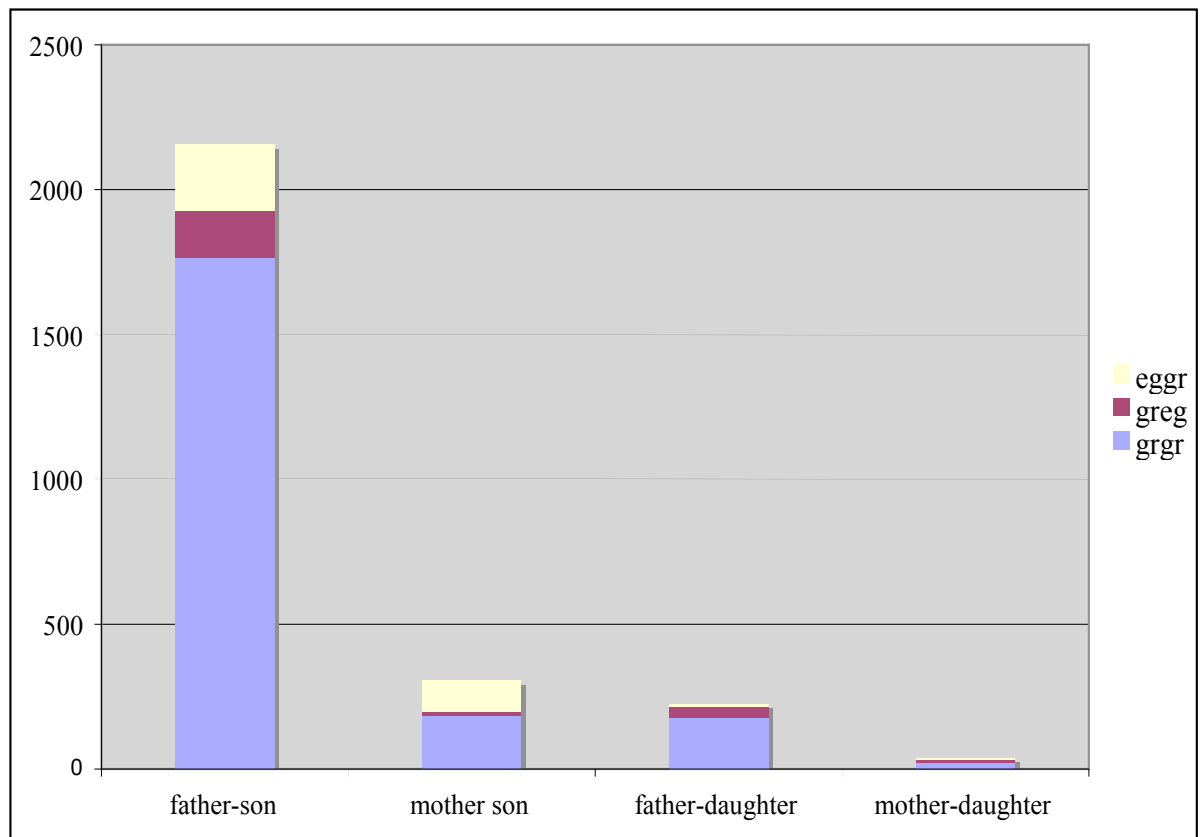

${ }^{34}$ A recent archaeological study confirms the essentially Greek character of the famous Alexandrian temple, see J. McKenzie, S. Gibson and A.T. Reyes, ,Reconstructing the Serapeum in Alexandria from the archaeological evidence', JRS 94 (2004) 73-121.

35 Within bilingual texts Sarapis is the Greek correspondent of Egyptian Osiris or Osiris-Apis, within Greco-Egyptian double names the Sarapis name functions as the Greek part. A typical instance is the bilingual SB III $6610=$ S.P. Vleeming, Some coins of Artaxerxes and other short texts (Studia Demotica 5, Leuven 2001) nr. 250, where Egyptian Pa-Min s3 P3-šr-Wsir (Paminis son of Psenosiris) is rendered in Greek as ,Paniskos son of Sarapion'. On the fallacy of the name Petosarapis, see now W. Clarysse, forthcoming in Elkab and beyond. Studies in honour of Luc Limme (Or. Lov. Anal. 191, Leuven 2009) 205-214. 


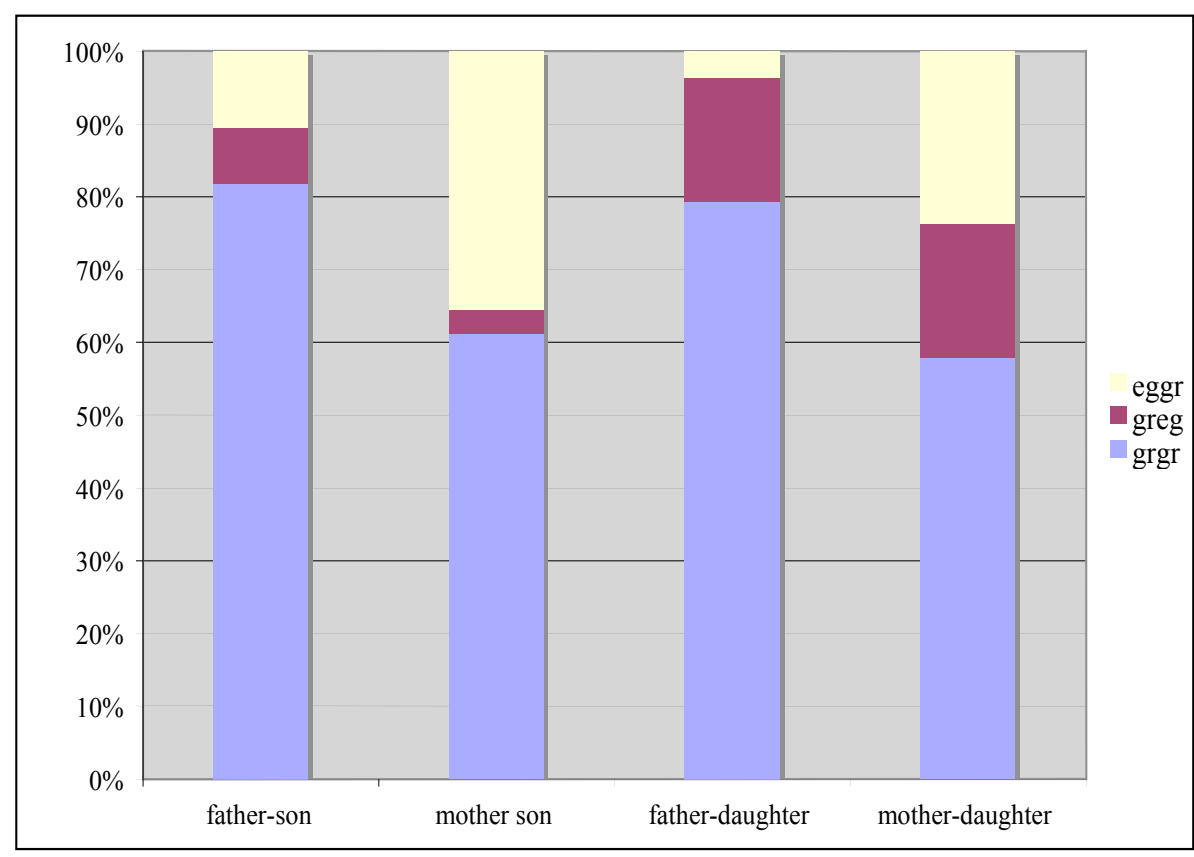

As is well-known, being Greek was more important for men than for women: ${ }^{36}$ over $90 \%$ of the sons of a Greek father have a Greek name, whereas $18 \%$ of the girls with a Greek father have an Egyptian name; similarly, almost 38\% of the sons with a Sarapis-name have a mother with an Egyptian name (col. ii, top), whereas Egyptian names are very rare for sons whose mother has a Greek (Sarapis-)name (5.6\%) (col. ii, middle). Daughters more easily receive an Egyptian name: about $20 \%$ of Greek fathers give their daughters an Egyptian name (col. iii, middle). Most noticeable is the small group (8 cases) but large percentage of Egyptian mothers who chose a Greek name for their daughter (col. iv, top). Rare female hybrid names are Tasarapis and Tasarapion, ${ }^{37}$ for which there is no male equivalent.

As a Greek name Sarapion was nevertheless felt to be typical of Egypt, a ,nom grec d'Égypte' as Bingen pointedly calls it. ${ }^{38}$ This is brought out well by a quip of

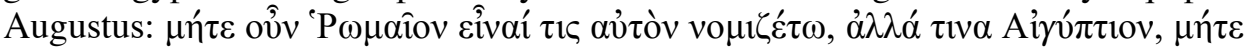

\footnotetext{
36 See, for instance, J. Bingen, ,Notables hermopolitains et onomastique féminine‘, $C E 66$ (1991) 324-9.

37 Tasarapis is found for a slave girl in P.Count. 50.123 (second century BC); for Tasarapion see P.Aberd. 56.6, 11; P.Oxy. VIII 1149; P.Oxy. Hels. 43.8; PSI X 1101.7 (second and third century AD).

38 J. Bingen, ,La dédicace O.G.I.S I 130‘, in J. Bingen, Pages d'épigraphie grecque: AttiqueÉgypte (1952-1982) (Epigraphica Bruxellensia 1, Bruxelles 1991) 103-104 n. 7. Cf. also R.S. Bagnall, ,The people of the Roman Fayum', in M.L. Bierbrier (ed.), Portraits and masks: burial customs in Roman Egypt (London 1997) 7-15 (re-published in R.S. Bagnall, Hellenistic and Roman Egypt. Sources and Approaches (Variorum collected studies series, Aldershot 2006) ch. XIV).
} 


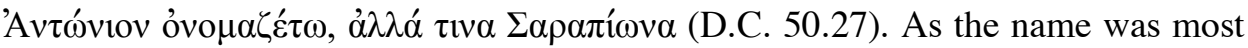
often found with Egyptians, it had a servile ring, as appears from a remark of Val. Max. 9.14.3 about P. Cornelius Scipio Nasica Serapio, consul of 138 BC. According to Valerius, Scipio received this seruilis appellatio (which he passed on to his son) because ,he looked very much like a merchant of victims whose name was Serapio'.

\section{Social Spread}

It is hardly possible to study the social spread of the Sarapis names for the Ptolemaic period because information about social standing is usually too vague. A few upper class Alexandrians were called Sarapion, including a dioiketes (PP I 46) and a governor of Cyprus ( $P P$ VI 15077), but Sarapis-names are almost entirely absent from the fasti of the eponymous priests ${ }^{39}$ and among the eponymous officers (PP II and VIII 1825-2035). They were certainly not typical of upper class society at that time.

For the Roman period, where we have more points of reference, we can trace the popularity of Sarapis names among the elite of Alexandrians, Antinoites, civil officials, councillors, gymnasium members and metropolitans. It is visible in their numbers (412 metropolitans and 196 Alexandrians; 342 of these are clearly elite, e.g. councillors, gymnasiarchs or stratêgoi). In this group the recurrence of Sarapis-names among succeeding generations is striking. But even here we reach the limits of our statistical approach, as metropolite landowners in the villages can only rarely be identified as such; on the other hand elite persons are more likely to occur in our documents and therefore they are better represented in the database than would be their actual percentage of the total population.

Ideally we should have a means to quantify different layers of the well-to-do and then again we should compare the number of Sarapis-names percentage-wise with the totals. Our impression is that Sarapis-names were especially popular with city people and elites, but proving this in a quantifiable way is still a far-off dream.

\section{Sarapis Names in Family Traditions}

In some cases Sarapion names recur over several generations within the same family. This looks like a typical feature of the urban population (metropolites, Antinoites, Alexandrians and elite in general), though again this is difficult to quantify.

\footnotetext{
39 One example of Sarapias and one of Sarapion on about 400 persons (priests, priestesses and their patronymics) in W. Clarysse and G. Van der Veken, The Eponymous Priests of Ptolemaic Egypt (Pap. Lugd. Bat. 24, Leiden 1983) nrs. 117-118 (174/73 BC) and 153 bis (138/37 BC).
} 


\begin{tabular}{|l|r|r|r|r|r|r|c|}
\hline & 3 BC & 2 BC & 1 BC & \multicolumn{1}{c|}{ AD 1 } & AD 2 & AD 3 & AD 4 \\
\hline sar & 34 & 122 & 100 & 422 & 2123 & 1295 & 482 \\
\hline sar2 & 0 & 4 & 12 & 64 & 250 & 102 & 12 \\
\hline$\%$ & 0 & $3 \%$ & $12 \%$ & $15 \%$ & $12 \%$ & $8 \%$ & $2,5 \%$ \\
\hline
\end{tabular}

Graph 4: Family traditions

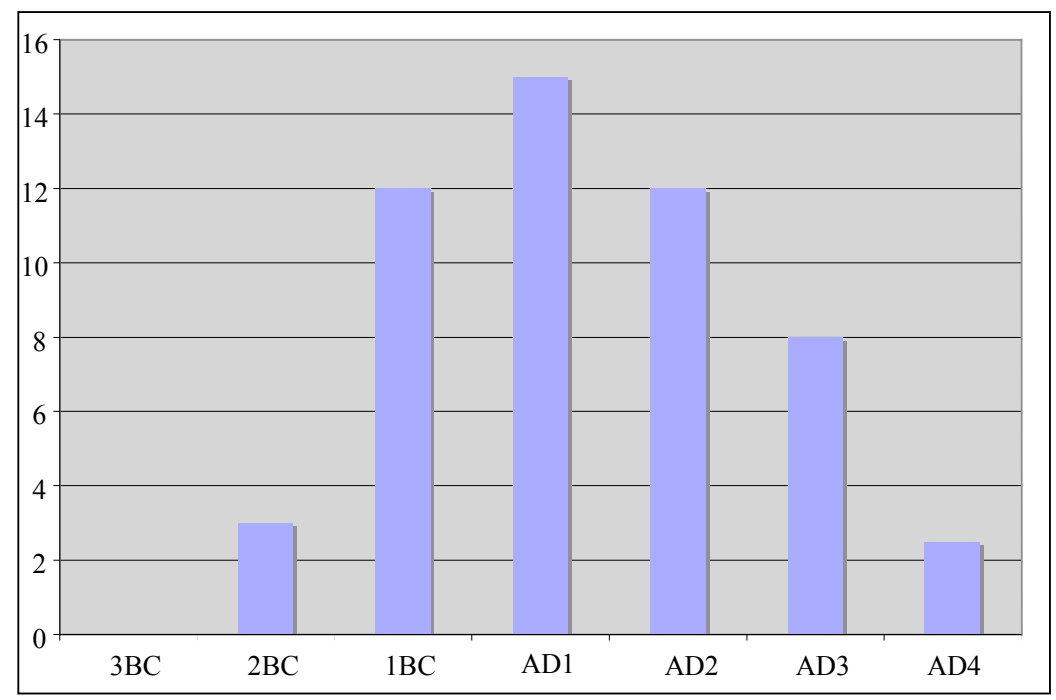

The graph shows in percentages how often Sarapis-names recur from one generation to the next (father-son, father-daughter, mother-son, mother-daughter), and over two generations (grandfather-grandson). Since the database counts each filiation twice (both father/mother and son/daughter have a Sarapis-name!), the number of filiations is only half our percentages. This causes no problem, however, for comparing the evolution over the centuries: how strong where family traditions with Sarapis-names? The graph clearly shows that the repetition of Sarapis names within the same families is strongest in the first century $\mathrm{AD}$ and that this led to the increasing number of names in the later period.

\section{The Christian Name Sarapion}

Whereas in the Ptolemaic and Roman periods Sarapis-names are found throughout Egypt, in the fifth to seventh centuries they are concentrated in the area of Hermoupolis and to a less extent the neighbouring nomes (Antinoopolis, Oxyrhynchite, Herakleopolite and in the 6th century Aphrodito). In the Arsinoite nome they nearly completely disappear. The difference between the fifth to

\footnotetext{
${ }^{40}$ Here we counted father-son, grandfather-grandson, father-daughter, mother-son and motherdaughter successions of a name with Sarapis.
} 
seventh centuries with the preceding period is so striking that a graph is unnecessary here. In the Oxyrhynchite nome Sarapammon becomes in the fifth century slightly more common than Sarapion, whereas in the Hermopolite nome Sarapion remains the more popular name throughout.

\begin{tabular}{|l|c|c|c|c|}
\hline & fourth cent. & fifth cent. & sixth cent. & seventh cent \\
\hline Arsinoites & 120 & $2^{41}$ & $1^{42}$ & $4^{43}$ \\
\hline Hermopolites & 73 & 48 & 40 & 35 \\
\hline Oxyrhynchites & 137 & 14 & 15 & $0^{44}$ \\
\hline Thebes-Aswan & 7 & 2 & 1 & 0 \\
\hline Aphrodito & 1 & 0 & 16 & 0 \\
\hline Lykopolites & 0 & 0 & 0 & 3 \\
\hline Antinoopolites & 12 & 0 & 7 & 1 \\
\hline Herakleopolites & 13 & 7 & 3 & 0 \\
\hline Delta & 5 & 2 & 0 & 0 \\
\hline unknown & 36 & 16 & 11 & 8 \\
\hline total & 404 & 90 & 94 & 51 \\
\hline
\end{tabular}

A saint called apa Sarapion had a sanctuary in Mounkrekis, in the Antaeopolite nome about AD 600. He is no doubt identical with the martyr Sarapion, whose festival on Choiach 17 is mentioned in an eight-century calendar of the Hermopolite nome. According to A. Papaconstantinou ${ }^{45}$ this martyr could be identical with Sarapion/Sarapammon (the two names got mixed up in the tradition), attested in Eusebius, in the synaxaries and in a Coptic saint's life. Sarapion/Sarapammon was a martyr from the Delta, apparently bishop of Nikiou, who died under Diocletian

41 The only certain instance is the priest Serapion in P.Haun. III 58.5 (= SB XIV 11357); O.Mich. I 87.2, dated by the editors to the fourth or fifth century, belongs nearly certainly to the fourth century (it comes from Karanis and mentions an Aurelius); the soldier Flavius Sarapammon in P.Lund. VI 10 comes from the Memphites. PUG I 27, dated on the basis of the handwriting,

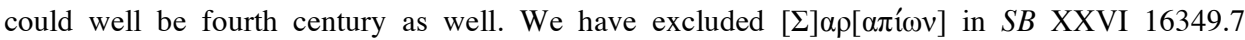
because the name is nearly completely supplemented and the supplement is unlikely in the seventh-century Arsinoites.

42 SB XVIII 13952.9 and 24: Sarapion son of Menas. The entries 4921 and 4922 in J. Diethart, Prosopographia Arsinoitica (MPER 12, Vienna 1980) 287 refer to a Hermopolite text. The reading of 4815 is doubted by Paganini (n. 8) 170 and that of 4817 is corrected by K.A. Worp (BL IX 459). As to nr. 4821: Stud.Pal. XX 252.13 is not from the Arsinoites but from the Oxyrhynchites (the village Teis); moreover the female name Sarapou[s] is unlikely as a grandfather's name (we have not included this reference in the database).

${ }^{43}$ For the seventh-century Arsinoites, P.Sijpesteijn 36.92 should be eliminated: $\Sigma \alpha \rho \alpha \pi(i \omega v)$ is an erroneous reading for Nar..u or Naar..u, no doubt a form of Naraou/Naroou (F. Morelli, who also prefers an eight-century date). Of the remaining four instances one is from Mouchis $(C P R$ XIX 45.4, AD 605; Sarapion is a patronymic) and three from the obscure village Kaminoi (P.Berl. Zilliacus 8.6 and 24; Wilcken, Chrest. 8.8 and 9).

44 The Oxyrhynchite provenance of P.Lond. V 1738 and 1744 is doubtful, see BL X 107.

45 A. Papaconstantinou, Le culte des saints en Egypte (Paris 2001) 184-5. 
and whose death was commemorated on different dates, but there is also a slight connection with Middle Egypt.

\section{The Compound Names Sarapammon, Sarap(i)odoros and Philosarapis}

Sarapammon combines Sarapis and Ammon, two gods closely connected with Zeus. For Sarapis this is clear from the iconography (beard, hair) and from dedications and oracle questions addressed to Zeus Helios Sarapis. ${ }^{46}$ The god

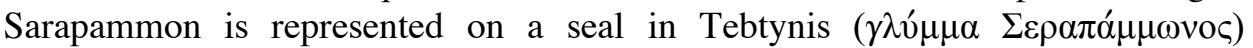
(P.Kron. 50; AD 138) and a temple to this composite deity is attested in the gymnasium quarter of Arsinoe, the capital of the Arsinoite nome (P.Turner 37.8; AD 270). In his iconographic representations the god combines features of Sarapis (the hair-locks on the forehead) and Ammon (the rams horns), but the most typical one, on the temenos wall at Deir el-Haggar (Dakhla oasis) identifies this god as Ammon, not as Sarapammon, as one would expect. ${ }^{47}$

In a 1963 article F. Dunand studied the personal names consisting of a divine name followed by Ammon, such as Souchammon, Dionysammon, Phoibammon and Sarapammon. ${ }^{48}$ She counted 238 items of Sarapammon at that time, all from the Roman period. In the meantime the number of attestations has more than doubled and we can now check her results on the basis of 525 persons. One can add 13 examples of Sarammon, no doubt a shortened form of Sarapammon. The short form is especially frequent in Oxyrhynchus and the western oasis. ${ }^{49}$

\footnotetext{
46 Cf. e.g. $S B$ V 8281; 8320; 8323; 8324; 8452; P.Oxy. IX 1213; XLII 3078. For the phrase ,Zeus Helios great Sarapis“ in inscriptions, $c f$. J.E. Stambaugh, Sarapis under the Early Ptolemies (EPRO 25, Leiden 1972) 79 n. 1.

${ }^{47} C f$. O.E. Kaper and K.A. Worp, ,Dipinti on the temenos wall at Deir el-Haggar (Dakhla Oasis)', BIFAO 99 (1999) 233-58 nrs. 17-18 with the dipinti nrs. 1-2; second century AD; other similar representations are referred to in their commentary on 244-5.

${ }^{48} \mathrm{~F}$. Dunand, ,Les noms théophores en -ammon. À propos d'un papyrus de Strasbourg du IIIe siècle p.C', CE 38 (1963) 134-6.

${ }^{49}$ In O.Douch II 59, however, we clearly read $\Sigma \alpha \rho \alpha \pi \alpha ́ \mu \mu \omega y$ instead of the editors’ $\Sigma \alpha \rho \alpha ́ \mu \mu \omega ̣$.
} 
Graph 5: Chronological distribution of Sarapammon

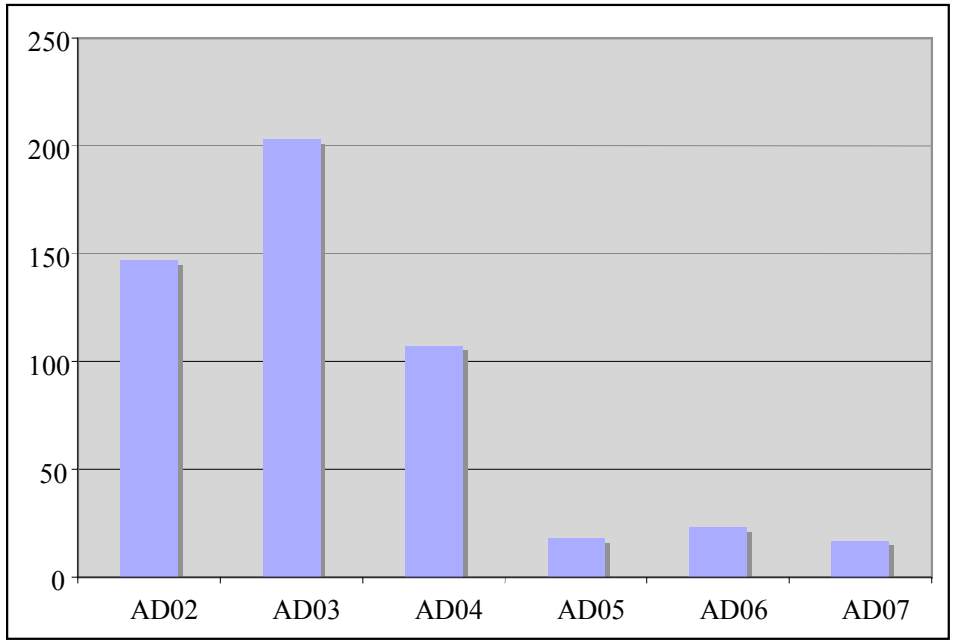

The first dated occurrences are a tax official in Elephantine in AD 123 (O.Wilcken 123 and 125), a boxer from the Arsinoites who bribed his opponent in Olympia in AD 125 (Paus. 5.21.15), an Arsinoite katoikos in AD 131 (CPR XV 23.3) and a member of an Alexandrian family in $\mathrm{AD} 138$ or 158 (P.Gen. II 111.10 with BL VIII 136)..$^{50}$ From AD 140 to the end of the fourth century the name is found all over Egypt. It lives on in the Christian period in Middle and Upper Egypt, but not in the Arsinoites, where it is not attested after AD 382 (P.Gen. I 68.7; a patronymic!). Sixty-eight cases, attributed by their editors to the period AD 100-199, or even more generally to the 'Roman period', can be safely dated after AD 120.51

Though Sarapammon is clearly a pagan name, it does not disappear with the victory of Christianity. The reason is no doubt the abovementioned martyr Sarapammon, bishop of Nikiou, who had a church in Alexandria in the sixth century. ${ }^{52}$

Sarapodoros and Philosarapis are far less common than Sarapammon. But their chronological curves are similar, as can be seen when their graphs are combined, except that Philosarapis disappears in the fourth century. Notice that Philosarapis

50 The Ptolemaic example in P.Ryl. IV 589 col. viii.8 was rightly dismissed by Dunand (n. 46) $138 \mathrm{n} .1$ (checked on the original by C.A. La'da). Dunand's earliest example is P.Strasb. I 27, but this text is dated to the late first or early second century AD on palaeographical grounds only. The name Valens (1.31) and especially Antoninus as a patronymic (1. 21), however, exclude a date before the second half of the second century.

${ }^{51}$ E.g. P.Alex. inv. 187.1; P.IFAO III 21.6; P.Thomas 11.5; O.Wilcken 1167 and 1212; SB I 441.3). J. Bingen, Pages d'épigraphie grecque: Égypte (1983-2002) (Epigraphica Bruxellensia 3, Bruxelles 2005) 135 already proposed AD 100 as a terminus post quem for texts in which compounds with -ammon occur.

52 Cosmas Indicopleustes, Topographie chrétienne 10.68 (Wolska-Conus ed.) 307 (reference found in Papaconstantinou (n. 44) 184). 
is not really a theophoric name: it is not paralleled for other gods (there is no such name as Philapollon or Philathena) and is rather linked with imperial epithets. The personal name precedes, however, by two generations the honorary titles of the prefect Ulpius Serenianus ${ }^{53}$ and of Caracalla. ${ }^{54}$ The name is particularly frequent in the Kharga oasis (12 instances on 42, vs. 10 for the Oxyrhynchite, 8 for the Arsinoite and 1 for the Hermopolite nome).

All three names appear in the second century AD. The first certain attestation of Sarapammon is in AD 123, of Philosarapis in 133 (for a one year old child) ${ }^{55}$ and of Sarapiodoros/ Sarapodoros in 142. The oldest examples of Sarapodoros are in fact written Sarapiodoros; the first certain example of Sarapodoros without iota dates from AD 174. Unlike Isis or Zeus Sarapis is not a child-giving god until quite late in his career, with the unexpected exception of P.Frankf. 4 from the mid third century BC (see above). Perhaps this was an early attempt to present Sarapis as a ,child giver", which did not stick.

It would be worthwhile to study this aspect of Greek (and Egyptian) onomastics - deriving from religion and myth - and asking why the virgin goddesses Athena and Artemis are givers of children (Athenodoros and Artemidoros are quite common names), whereas Hera, Aphrodite and Poseidon are not. In the Egyptian tradition Petosiris (,Given by Osiris') is as common as Peteesis, and Petosorapis is found sporadically in Ptolemaic papyri, but Sarapis has not taken over this role of Osiris or Osorapis until quite late and even then only reluctantly. Note that Osorapis can be linked to Pete- ,given by', but not to Psen-, son of ${ }^{6}$. In Egyptian onomastics too the combinations of prefixes (Psen-, Pete-, Pa-) and divine names are subject to restrictions and a quantitative study of these possibilities may teach us something about the nature of the gods. ${ }^{56}$

\footnotetext{
53 SB XIV 11342.6, linked to Commodus' devotion for Sarapis by P.J. Parsons, ,Ulpius Serenianus', $C E 49$ (1974) 142.

54 Most recent discussion by A. and E. Bernand in F. Goddio, A. Bernand and E. Bernand, ,L'épigraphie sous-marine dans le port oriental d'Alexandrie', ZPE 121 (1998) 139-40.

55 We have not counted the familia of Philoserapi( ) in O.Claud. 115 (AD 100-120), because it is the name of a quarry, not that of a person.

${ }^{56}$ See, most recently, Clarysse and Thompson 2 (n. 3) 334-5.
} 
Graph 6: Chronological distribution of the names Sarapodoros and Philosarapis

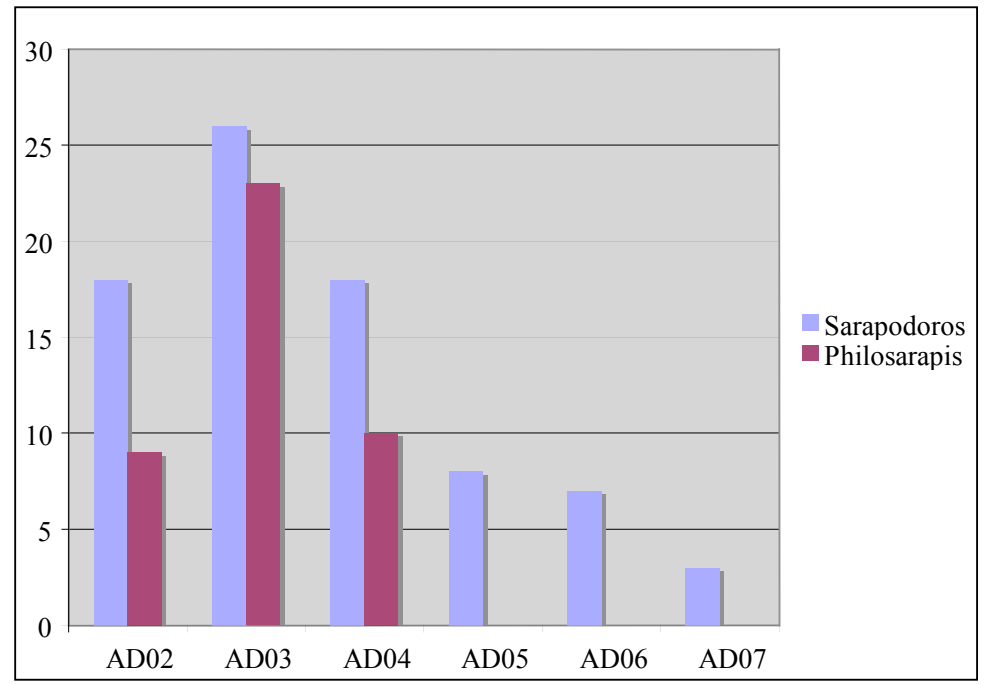

Counting the number of attestations of the three Sarapis-names by century for each thousand texts (as on pp. 72-73), we can see the evolution over time and also compare them to one another in the following graph:

Graph 7: Frequency of Sarapammon, Sarapodoros and Philosarapis

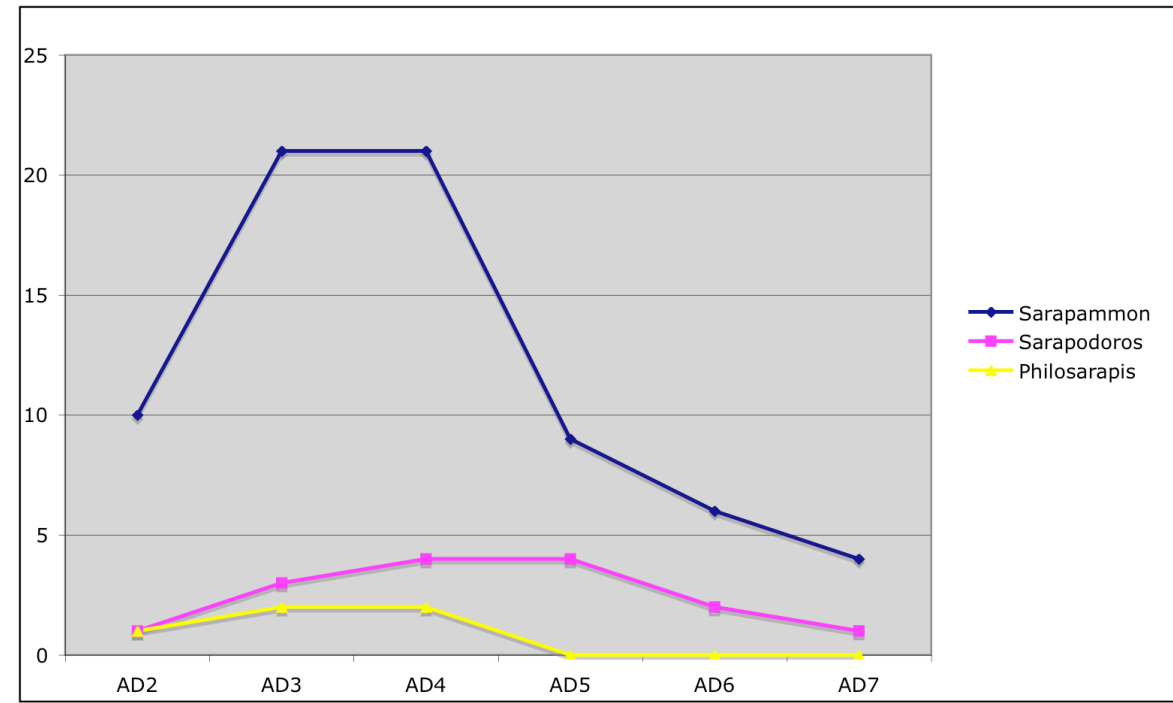

Sarapammon is by far the most common of the three. However, the number of attestations for Philosarapis is too small for relevant statistics, especially as a quarter of the 43 references come from the western oasis (Kellis). 
Some rare names can not be treated statistically: Sarapiades occurs 15 times between 102 and 307. All examples, except the doubtful I.Portes 5.8 and a letter from the Mons Claudianus (O.Claud. 138) come from Oxyrhynchus. Sarapiakos is attested 16 times; the earliest dated instance is from AD 153 (O.Claud. III 595) and the latest from AD 332 (P.Oxy. XLIII 3127.5). This name is again typical of Oxyrhynchus. ${ }^{57}$ The compounds Sarapodidymos and Sarapodioskoros are found only in SEG 51.2159, a catalogue of ephebes participating in sacred games (Leontopolis, AD 220). Sarapollo is found three times in all. ${ }^{58}$ Diosarapis in P.Bub. II 5 passim (Bubastos, AD 205/6), Saranoupis in SB I 5272.31 (Memphis, AD 304), Sarapaphrodisios (Stud. Pal. XXII 3.6; 2nd cent.) and the feminine Sarapiaina in P.Lips. I 33 (Hermopolites, AD 368) are hapax legomena.

\section{The Hypocoristics Sarapas, Sarapous and Saras}

Graph 8: The hypocoristics Sarapas, Sarapous and Saras (unscaled and scaled, i.e. number of names on 1000 texts)

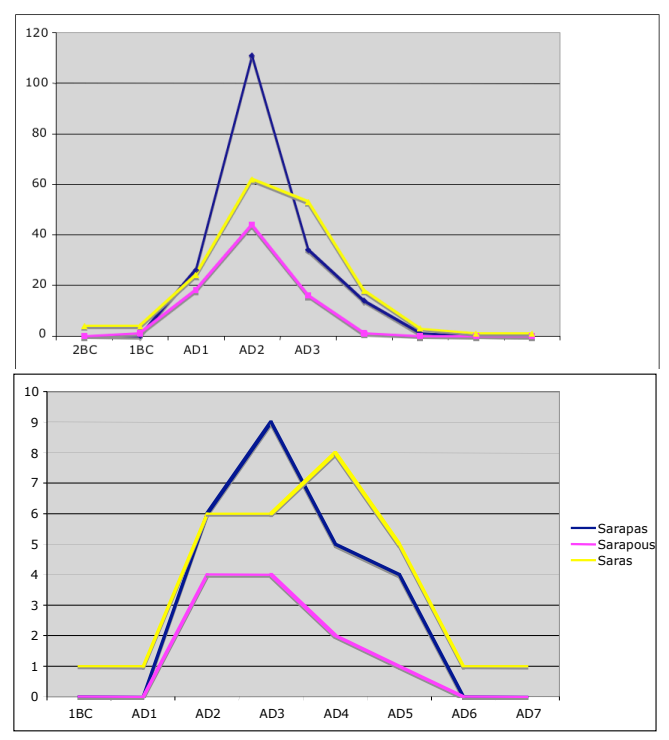

${ }^{57}$ Exceptions are PGM XXXIIa (found in Hawara); SB XXVI 16644.65 (Arsinoites); O.Claud. III 595 and P.Oslo III 129.5 (Antinoopolis; slave).

58 P.Brux. I 18.2, 16, 28 (Delta; AD 174); BGU II 649 (Sarapapollon, an Alexandrian in the Delta; AD 187); CPR XVIIA 17.3 (Hermoupolis; AD 317). 
Graph 9: Sarapas, Sarapous and Saras, geographical distribution

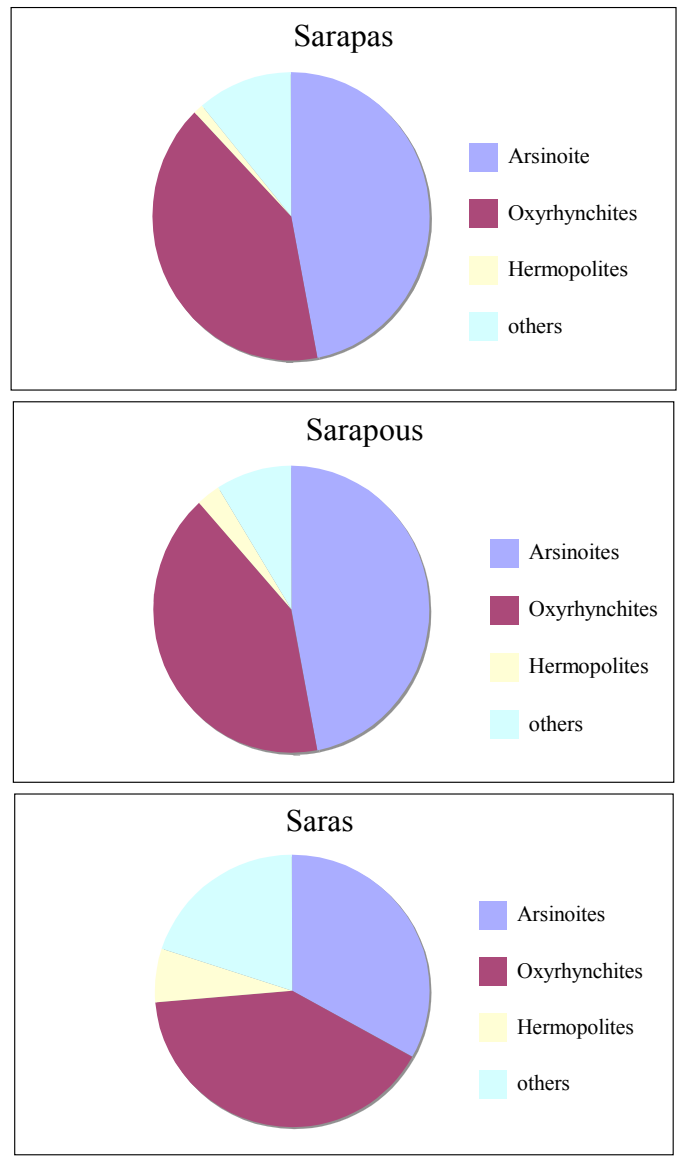

Sarapous is the feminine form of Sarapas, ${ }^{59}$ and the few apparent exceptions are probably due to errors of reading or interpretation of the editors. ${ }^{60}$

Sarapas, ${ }^{61}$ Sarapous and Saras present a nearly identical curve, with a peak in the second and third centuries AD (the peak in absolute numbers is due to the

59 There are no certain instances of persons called Sarapion alias Sarapas. In P.Flor III 382.85 a woman is called Sarapias alias Sarapous (she has a brother Sarapion). Saras son of Belles and Sarapion son of Belles occur side by side in $S B$ XX 14409, but identity cannot be proven: they may for instance be brothers. In P.Oxy. X 1269 Sarapas and Sarapous, children of Isidoros, are apparently brother and sister.

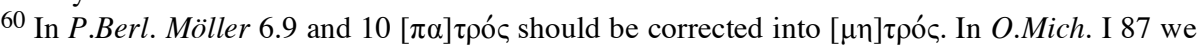

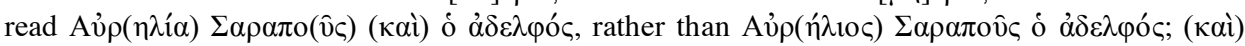
was already proposed by H.C. Youtie: $c f$. the note on the APIS site at www.columbia.edu/cu/l web/projects/digital/apis s.v. O.Mich. I 87). In I.Louvre $89 \Sigma \alpha \rho \alpha \pi$ ṿ̂ (the editor É. Bernand incorrectly translates ,fils de Sarapas') is apparently a patronymic in the genitive, but probably this deceased is identified here by his mother's name. 
large number of papyri in the second century). Only Saras occurs already in the Ptolemaic period; the earliest instances of Sarapas and Sarapous are in AD 21 (P.Aberd. 66) and AD 48 (P.Mich. V 326). The three names are common in the Arsinoites (79 Sarapas, 34 Sarapous, 55 Saras) and the Oxyrhynchites (69 Sarapas, 28 Sarapous, 67 Saras), but rare in the Hermopolites (2 doubtful examples for Sarapas and Sarapous, ${ }^{62} 10$ examples for Saras) ${ }^{63}$ and elsewhere. Here the names may help to localise individual texts.

There are two problems with the name Saras, which is probably a shorter hypocoristic of Sarapion. When this name is feminine, we have considered it a Greek rendering of the Jewish name Sarah, which has nothing to do with Sarapis. ${ }^{64}$ The variant form Seras has also been omitted, as this can also be a hypocoristic of Latin Serenus, as in the double name Serenus alias Seras in P.Hamb. I 43 1. 11. In SB XVI 12339.3 the filiation Seras son of Herakles grandson of Saras suggest a Sarapis-name, but in the majority of cases there is no way to decide and for this reason Seras has not been taken into account.

\footnotetext{
${ }^{61}$ A clear indication that Sarapas does indeed function as a hypocoristic of Sarapion is found in P.Mich. V 246, where the witness Serapas son of Ptolemaios (1. 17) signs himself with the name Sarapion son of Ptolemaios (1. 20). Cf. also I.Smyrna 525, where a dead child is called Sarapas in the verse inscription (no doubt metri causa) and Sarapion in the preceding prose text.

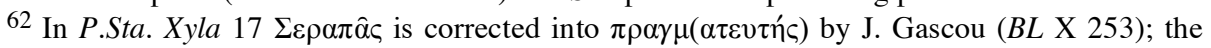
Hermopolite provenance of P.Sta. Xyla 7 is not certain; Sarapous in P.Lips. I 10 is from the Koussites; P.Flor. III 382.85, 89 is found in Hermoupolis, but deals with Alexandrian citizens.

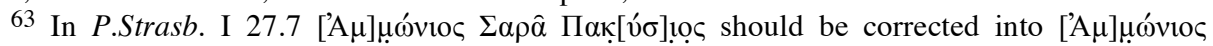
$\Sigma \alpha \rho \alpha \pi \alpha ́ \mu[\mu \omega]$ yọ (reading checked on the original by P. Heilporn).

${ }^{64}$ Cf. e.g. P.Count 34.6 for the Ptolemaic period and P.Oxy. XVII 2195.189 for Sarah as a Jewish-Christian name in the sixth century AD. The only exception is SB XVI 12515 col. ii.9 and 19 , where Saras is the daughter of Thoo(nis) in a text from the first century AD.
} 